\title{
Studies of the Relationship between Morphology and Pozzolanic Activity of Different Micro Fillers for HPC
}

\author{
Linda Krage ${ }^{1}$, Diana Bajare ${ }^{2}$, Aleksandrs Korjakins ${ }^{3}$, Janina Setina ${ }^{4}$, Inna Juhnevica ${ }^{5}$, Inta Kirilovica ${ }^{6}$, \\ ${ }^{1-6}$ Riga Technical University
}

\begin{abstract}
The given research is devoted to the studies of morphology, particle size and pozzolanic activity of different supplementary cementing materials $(\mathrm{SCM})$ - thermally treated clays as well as waste products - coal ash, waste glass powder, timber and barley ashes. Different properties of SCM have been analysed: specific surface area, surface morphology, particle size distribution, chemical composition and lime-combining capacity in the reaction with $\mathrm{Ca}(\mathrm{OH})_{2}$. The obtained results have indicated that micro additives with larger specific surface are more reactive.
\end{abstract}

Keywords - Cementing materials, micro fillers, morphology, pozzolanic activity, surface area.

\section{INTRODUCTION}

Traditional concrete has four components: cement, water, fine aggregates, and coarse aggregates. For modern or advanced concrete technology, various mineral admixtures have been widely used in concrete constructions. The purposes of using these mineral admixtures in concrete are to gain economic benefits, protect the environment, improve the workability of fresh concrete, enhance strength, and especially the durability of hardened concrete, and decrease hydration heat [1]. Mineral admixtures are usually divided in siliceous and/or aluminous materials that are added to concrete during mixing. Many researchers also call them supplementary cementing materials (SCM). Four commonly used mineral admixtures are the following: silica fume, slag, fly ash, and metakaoline [1].

Metakaoline is produced by calcining Kaoline clay. The material is an aluminosilicate that reacts with free lime in a similar manner as silica fume [2]. When clay or shale is calcined at the temperature of $700{ }^{\circ} \mathrm{C}$ to $800{ }^{\circ} \mathrm{C}$, the clay is dehydrated and its crystalline structure is totally disorganized. Silicon 28etrahedral becomes active so that it can react at ambient temperature with the lime liberated by the hydration of cement mineral alite or tricalcium silicate $\left(\mathrm{C}_{3} \mathrm{~S}\right)$ and tetracalcium aluminate ferrite $\left(\mathrm{C}_{4} \mathrm{AF}\right)$ [3]. Metakaoline improves concrete performance by the packing effect and by reacting with calcium hydroxide, to form secondary calcium silicate hydrates (CSH) [1].

It is evident that particle surface texture has some influence on the strength of the aggregate-cement paste bond, but difficulty of measurement means that the property is rarely considered and almost never the subject of a specification requirement. The effects of particle shape and surface texture on workability are seemingly more pronounced for fine aggregates, in which particle geometry is more difficult to characterize [4].

\section{EXPERIMENTAL PROCEDURE}

\section{A. Materials}

The following supplementary cementing materials were studied: metakaoline - kaolinite clay, calcined at $700{ }^{\circ} \mathrm{C}(\mathrm{MK})$; Devonian clay, Liepa deposit, Latvia, calcined at the temperature of $700{ }^{\circ} \mathrm{C}$ (DC); borosilicate glass powder (BSG); lead silicate glass powder (LSG); coal ash (CA); wood ash (WA) and barley ash (BA).

In the current study, metakaoline (MK) was obtained in the laboratory furnace by the calcination of commercially available kaolinite clay at the temperature of $700{ }^{\circ} \mathrm{C}$. The sintering process of MK used in this study lasted approximately 3 hours with temperature increase of $15^{\circ} \mathrm{C} / \mathrm{min}$ and holding of $\mathrm{MK}$ in the maximum temperature $\left(700^{\circ} \mathrm{C}\right)$ for 1 hour. After calcination MK was ground in the laboratory planetary ball mill Retsch PM 400 for $15 \mathrm{~min}, 20 \mathrm{~min}$ and $30 \mathrm{~min}$ at a speed of $300 \mathrm{rpm}$.

Devonian clay (DC) was also calcinated at the temperature of $700{ }^{\circ} \mathrm{C}$, by using a slow calcination regime (heating rate of $10^{\circ} \mathrm{C} / \mathrm{min}$, kept at the maximum temperature for $3 \mathrm{~h}$ ). Already calcinated clay was ground in planetary ball mill Retsch PM400 for $15 \mathrm{~min}, 20 \mathrm{~min}$ and $30 \mathrm{~min}$ at a speed of $300 \mathrm{rpm}$.

The coal ash (CA), i.e., coal combustion bottom ash used in the research comes from a boiler house operating on coal. CA was ground for different grinding periods $-4 \mathrm{~min}, 15 \mathrm{~min}$, $30 \mathrm{~min}$ and $45 \mathrm{~min}$ respectively.

Both applied glass types are the by-products and were selected for studies, due to the high content of amorphous $\mathrm{SiO}_{2}$. Borosilicate glass powder (BSG) and lead silicate glass powder (LSG) were obtained from the local lamp recycling [5]. The chemical composition of both glass powders is given in Table 1 .

Wood and barley ashes used in given experiments were taken from the local heating plant furnaces in Latvia. In order to obtain material with homogenous composition, ashes were ground in the already mentioned laboratory ball mill for the period of $4 \mathrm{~min}$, at the grinding speed of $300 \mathrm{rpm}$.

The chemical compositions of each SCM are summarized in Table 1. In Table 2, the treatment (burning or grinding) along with designation is given. 
TABLE 1

CHEMICAL COMPOSITION OF SCM USED FOR STUdIES

\begin{tabular}{|c|c|c|c|c|c|c|c|c|}
\hline \multirow{2}{*}{$\begin{array}{c}\text { Chemical } \\
\text { composition, } \\
\text { wt } \%\end{array}$} & \multicolumn{7}{|c|}{$\mathrm{SCM}$} & \multirow[b]{2}{*}{ St.dev., $\%$} \\
\hline & $\begin{array}{l}\text { Metakaoline } \\
\text { (MK), wt } \%\end{array}$ & $\begin{array}{c}\text { Devonian } \\
\text { clay (DC), wt } \%\end{array}$ & $\begin{array}{l}\text { Coal ash } \\
\text { (CA), wt } \%\end{array}$ & $\begin{array}{l}\text { Borosilicate } \\
\text { glass powder } \\
\text { (BSG), wt } \%\end{array}$ & $\begin{array}{l}\text { Lead silicate } \\
\text { glass powder } \\
\text { (LSG), wt\% }\end{array}$ & $\begin{array}{l}\text { Wood ashes } \\
\text { (WA), wt } \%\end{array}$ & $\begin{array}{l}\text { Barley straw ashes } \\
\text { (BA), wt } \%\end{array}$ & \\
\hline $\mathrm{SiO}_{2}$ & 51.52 & 70.78 & 15.96 & 74.20 & 69.07 & 59.92 & 66.07 & \pm 0.5 \\
\hline $\mathrm{Al}_{2} \mathrm{O}_{3}$ & 40.18 & 13.89 & 26.56 & 1.65 & 1.03 & 4.30 & 5.38 & $\pm 0.3-0.5$ \\
\hline $\mathrm{Fe}_{2} \mathrm{O}_{3}$ & 1.23 & 4.00 & 0.86 & 0.16 & 0.19 & 1.60 & 1.78 & $\begin{array}{l} \pm 0.03- \\
0.5\end{array}$ \\
\hline $\mathrm{CaO}$ & 2.00 & 1.32 & 10.30 & 2.09 & 1.39 & 19.89 & 6.06 & $\pm 0.2-0.5$ \\
\hline $\mathrm{MgO}$ & 0.12 & 0.67 & 2.17 & - & - & 2.32 & 1.68 & $\pm 0.2-0.5$ \\
\hline $\mathrm{K}_{2} \mathrm{O}$ & 0.53 & 3.36 & - & 0.93 & 1.17 & 3.59 & 7.14 & $\pm 0.1-0.5$ \\
\hline $\mathrm{Na}_{2} \mathrm{O}$ & 0.08 & 0.06 & - & 3.82 & 8.02 & 0.37 & 0.24 & $\pm 0.1-0.5$ \\
\hline $\mathrm{TiO}_{2}$ & 2.27 & - & - & - & - & - & - & $\pm 0.3-0.5$ \\
\hline $\mathrm{SO}_{3}$ & 0.00 & - & 0.50 & - & - & - & - & $\pm 0.1-0.5$ \\
\hline $\mathrm{C}$ & - & - & 29.40 & - & - & - & - & \pm 0.5 \\
\hline $\mathrm{PbO}$ & - & - & - & - & 20.02 & - & - & \pm 0.5 \\
\hline $\mathrm{B}_{2} \mathrm{O}_{3}$ & - & - & - & 16.63 & - & - & - & \pm 0.5 \\
\hline LOI & 2.01 & 2.62 & 14.32 & - & - & 6.65 & 11.05 & \pm 0.3 \\
\hline Total & 99.94 & 96.70 & 100.00 & 99.48 & 100.00 & 98.64 & 99.39 & \\
\hline
\end{tabular}

Regarding the chemical analysis, the attention was first of all paid to the content of $\mathrm{SiO}_{2}$ and $\mathrm{Al}_{2} \mathrm{O}_{3}$, as those compounds are expected to play a main role in a pozzolanic reaction. DC, BSG and LSG exhibit the largest content of $\mathrm{SiO}_{2}-$ around $70 \mathrm{wt} \%$, also in wood and barley ashes it is rather high $60 \mathrm{wt} \%-66 \mathrm{wt} \%$, the lowest is observed in CA - only around $16 \mathrm{wt} \%$. MK has the highest content of $\mathrm{Al}_{2} \mathrm{O}_{3}-$ around $40 \mathrm{wt} \%$, then CA follows with $27 \mathrm{wt} \%$ and DC with $14 \mathrm{wt} \%$. For the rest of additives, content of $\mathrm{Al}_{2} \mathrm{O}_{3}$ is insignificantly low.

TABLE 2

DESIGNATION AND PREPARATION CONDITIONS OF SCM

\begin{tabular}{|r|l|}
\hline \multicolumn{1}{|l|}{ Description of SCM } & Designation \\
\hline Kaolinite clay, burned at $700{ }^{\circ} \mathrm{C}$, grinding time: $15 \mathrm{~min}$ & MK 15 \\
\hline grinding time: $20 \mathrm{~min}$ & MK 20 \\
\hline grinding time: $30 \mathrm{~min}$ & MK 30 \\
\hline Devonian clay, burned at $700{ }^{\circ} \mathrm{C}$, grinding time: $15 \mathrm{~min}$ & DC 15 \\
\hline grinding time: $20 \mathrm{~min}$ & DC 20 \\
\hline grinding time: $30 \mathrm{~min}$ & DC 30 \\
\hline Borosilicate glass waste, grinding time: $30 \mathrm{~min}$ & BSG \\
\hline Lead silicate glass waste, grinding time: $30 \mathrm{~min}$ & LSG \\
\hline Coal ash, grinding time: 4 min & CA 4 \\
\hline grinding time: $15 \mathrm{~min}$ & CA 15 \\
\hline grinding time: $30 \mathrm{~min}$ & CA 30 \\
\hline grinding time: 45 min & CA 45 \\
\hline Wood ash & WA \\
\hline Barley ash & BA \\
\hline
\end{tabular}

\section{B. Methods}

In order to characterize the relationship between particle morphology and their pozzolanic activity of selected SMC, data obtained by different methods were compared:

- particle shape and morphology - by scanning electron microscopy (SEM - TESCAN MiralLMU FieldEmission-Gun);

- specific surface area of particles - by Porosimeter NOVA 1200E (0.35 nm - $200 \mathrm{~nm})$ "Quantachrome Instruments";

- content of reactive $\mathrm{SiO}_{2}, \mathrm{Al}_{2} \mathrm{O}_{3}$ and $\mathrm{Fe}_{2} \mathrm{O}_{3}$ of particles according to the Florentine method [6], [7];

- ability to react with $\mathrm{Ca}(\mathrm{OH})_{2}$ (described below [8], [9]);

- measurements of particle size - by "90 Plus", "Brookhaven Instr".

The measurements of pozzolanic activity are based on the reaction between free lime and pozzolanic additive or SCM. During pozzolanic reaction, the free lime reacts with pozzolanic additive; thus, the simplest way how to follow the dynamics of pozzolanic reaction is either to measure the amount of calcium hydroxide or the amount of unreacted pozzolana. For the experiment, $1 \mathrm{~g}$ of SCM is mixed with $75 \mathrm{ml}$ of saturated $\mathrm{Ca}(\mathrm{OH})_{2}$. Then after different periods of time (in given case after 3 and 24 hours), the amount of absorbed $\mathrm{Ca}(\mathrm{OH})_{2}$ was measured by titration with $0.1 \mathrm{n} \mathrm{HCl}$ solution. The results are expressed as the amount of reactive $\mathrm{CaO}$ (wt\%). Results, obtained by different methods are summarized in Tables 3-7.

\section{RESULTS}

\section{A. Particle Shape and Morphology (SEM)}

Images, characterizing the particle shape and morphology obtained by SEM, are depicted in Table 3. 
TABLE 3

SEM MICROGRAPHS OF SCM

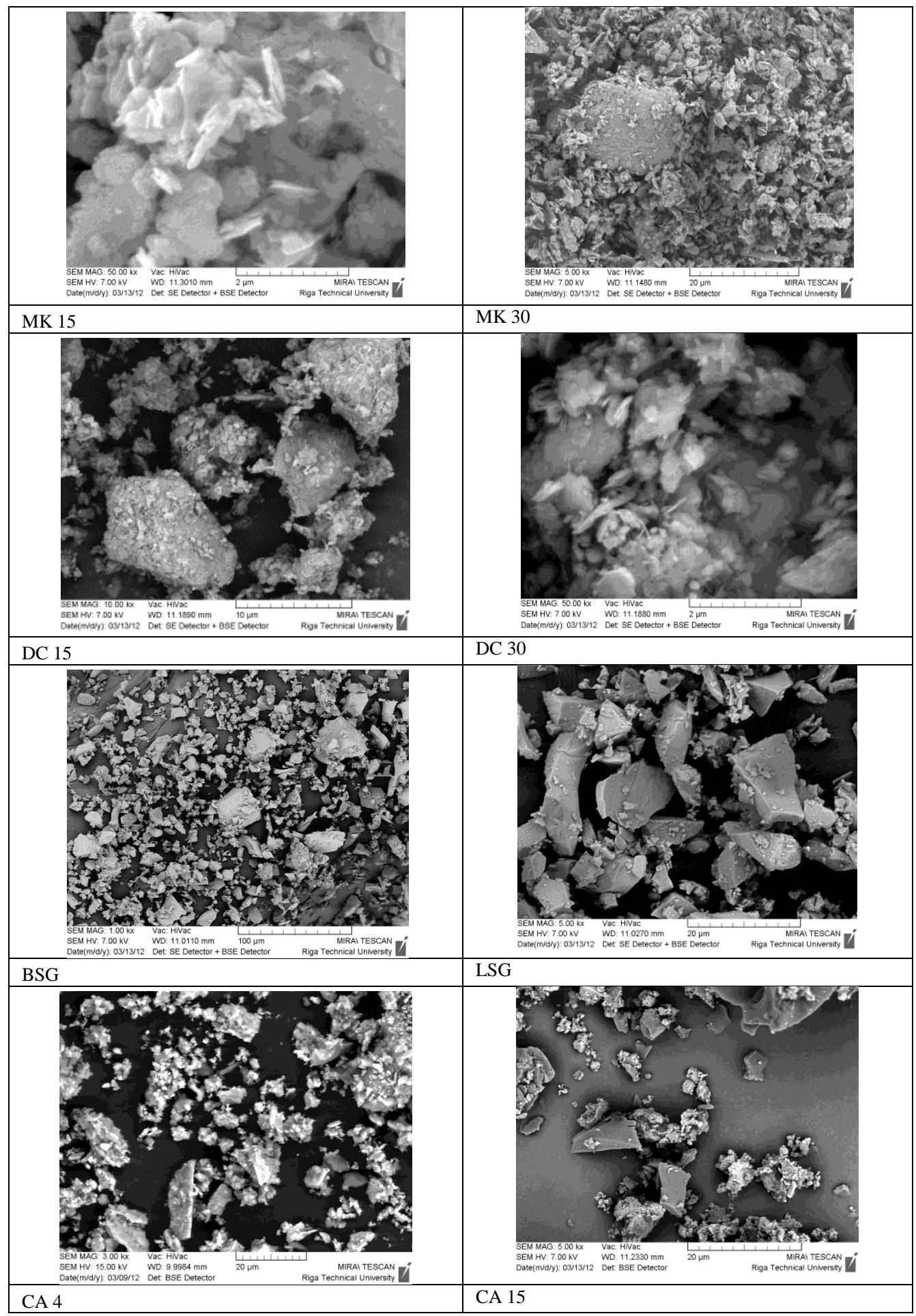


SEM

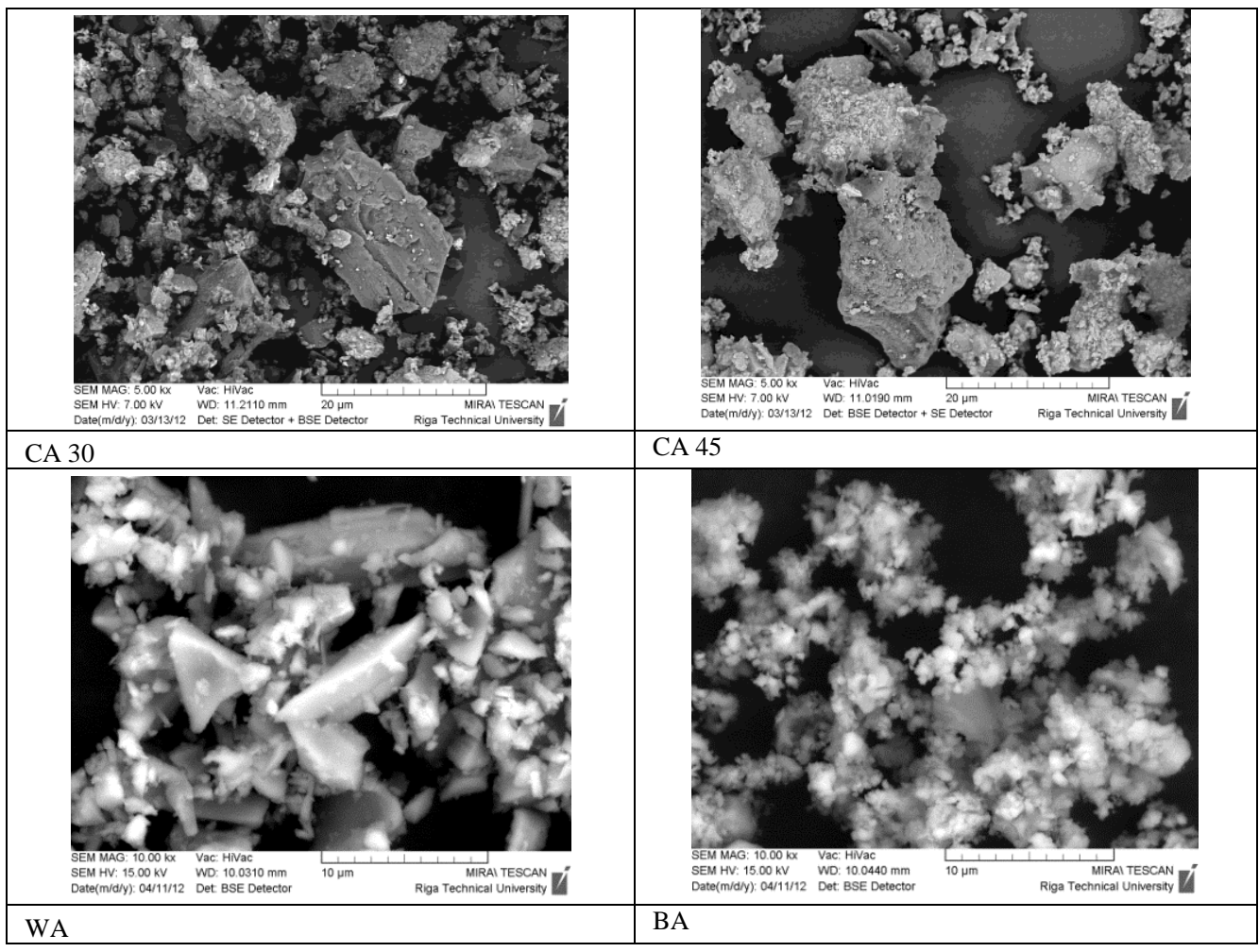

The shape of both clay particles - metakaoline (MK) and Devonian clay $(\mathrm{DC})$ - is rather similar. Both have a lamellar shape characteristic of clay materials. For Devonian clay, the margins of plates are little bit more rounded than for kaolinite particles. For the particles obtained from waste glass, the shape is irregular, sharp-edged with smooth surface (glass powder BSG and LSG). Shape of CA particles is rather similar independently of the treatment parameters - irregular, angular, with porous surface. Regarding wood and barley ashes (bio ashes), the shape of particles could be compared with glass powder particles, as it is irregular and angular.
B. Pozzolanic Activity and Content of Reactive $\mathrm{SiO}_{2}$ and $\mathrm{R}_{2} \mathrm{O}_{3}$

Content of reactive $\mathrm{SiO}_{2}$ and $\mathrm{R}_{2} \mathrm{O}_{3}$ (common amount of $\mathrm{Al}_{2} \mathrm{O}_{3}, \mathrm{Fe}_{2} \mathrm{O}_{3}$ and $\mathrm{TiO}_{2}$ ), detected by chemical analysis as well the pozzolanic activity, measured after 3 and 24 hours in reaction with $\mathrm{Ca}(\mathrm{OH})_{2}$, expressed as the amount of reactive $\mathrm{CaO}(\mathrm{wt} \%)$ is summarized in Table 4.

\section{Particle Size and Specific Surface Area}

The specific surface area of studied SCM, measured by BET, and the particle size, measured by DSL (as min/max and average) are summarized in Table 5.

TABLE 4

Content of Reactive $\mathrm{SiO}_{2}$ And $\mathrm{R}_{2} \mathrm{O}_{3}$, AS well the Pozzolanic Activity, Measured in Reaction with Ca(OH $)_{2}$

\begin{tabular}{|l|l|l|l|}
\hline $\mathrm{SCM}$ & Content of reactive $\mathrm{SiO}_{2} / \mathrm{R}_{2} \mathrm{O}_{3}, \mathrm{wt} \%$ & $\begin{array}{l}\text { Pozzolanic activity after 3 } \mathrm{h} \\
(\text { amount of CaO, wt } \%)\end{array}$ & $\begin{array}{l}\text { Pozzolanic activity after 24 } \mathrm{h} \\
(\mathrm{amount} \text { of CaO, wt\% })\end{array}$ \\
\hline MK 15 & $1.10 / 32.76$ & 0.0392 & 0.0483 \\
\hline MK 30 & $1.91 / 32.47$ & 0.0336 & 0.0483 \\
\hline DC 15 & $1.02 / 6.73$ & 0.0319 & 0.0332 \\
\hline DC 30 & $1.05 / 7.79$ & 0.0430 & 0.0357 \\
\hline BSG & $0.50 / 0.36$ & 0.0269 & 0.0095 \\
\hline LSG & - & 0.0157 & 0.0157 \\
\hline CA 4 & $1.51 / 6.35$ & 0.0402 & 0.0220 \\
\hline CA 45 & $2.13 / 7.37$ & 0.0340 & 0.0203 \\
\hline WA & $4.88 / 4.04$ & 0.0084 & 0.0500 \\
\hline BA & $0.56 / 2.56$ & 0.0179 & 0.0078 \\
\hline
\end{tabular}


TABLE 5

PARTICLE SIZE AND SPECIFIC SURFACE AREA, $\mathrm{M}^{2} / \mathrm{G}$

\begin{tabular}{|l|l|l|l|}
\hline SCM & Surface $a r e a, \mathrm{~m}^{2} / \mathrm{g}$ & Min / max particle size, $\mathrm{nm}$ & $\begin{array}{l}\text { Dominating particle size }(50 \%), \\
\mathrm{nm}\end{array}$ \\
\hline MK 15 & 16.52 & $739 / 923$ & 840 \\
\hline MK 30 & 15.86 & $476 / 600$ & 541 \\
\hline DC 15 & 21.95 & $177 / 697$ & 542 \\
\hline DC 30 & 21.42 & $702 / 886$ & 799 \\
\hline BSG & 1.126 & - & - \\
\hline LSG & 0.252 & $538 / 678$ & 612 \\
\hline CA 4 & 11.64 & $1832 / 2312$ & 2084 \\
\hline CA 45 & 9.849 & $776 / 979$ & 883 \\
\hline WA & 0.293 & $1364 / 3190$ & 2464 \\
\hline BA & 0.480 & $914 / 1153$ & 1039 \\
\hline
\end{tabular}

\section{DISCUSSION}

The shape of both clay particles - metakaoline (MK) and Devonian clay (DC) - is rather similar. Both have a lamellar shape characteristic of clay materials. The values of specific surface are also rather close - around 16 for $\mathrm{MK}$ and $21 \mathrm{~m}^{2} / \mathrm{g}-22 \mathrm{~m}^{2} / \mathrm{g}$ for DC. However, the longer grinding time in both cases does not provide the larger specific surface (see Table 5).

As the specific surface area for DC is slightly larger than for MK, it could be expected that the Devonian clay would be more effective as pozzolanic additive than metakaoline, however the chemical analysis indicates higher values of reactive $\mathrm{SiO}_{2}$ and $\mathrm{R}_{2} \mathrm{O}_{3}$ in metakaoline, if to compare with calcinated Devonian clay. Respectively, if the amount of reactive $\mathrm{SiO}_{2}$ in metakaoline is $1.10 \% \ldots 1.85 \%$ and $\mathrm{R}_{2} \mathrm{O}_{3}$ is $32.19 \% \ldots 32.76 \%$, then in Devonian clay the numbers are lower $-\mathrm{SiO}_{2}-$

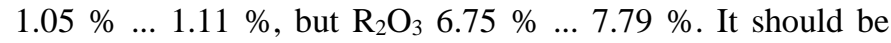
mentioned that in both clays the amounts of reactive $\mathrm{SiO}_{2}$ are very close - around $1 \%$; however, the amount of reactive $\mathrm{Al}_{2} \mathrm{O}_{3}$ differs significantly.

According to Table 4, after 3 hours of reaction with $\mathrm{Ca}(\mathrm{OH})_{2}$, MK 15 is more active than MK 30, the pozzolanic activity for both is 0.0392 (MK 15) and 0.0336 (MK 30), respectively. Although the values are rather close, it could indicate that longer time of grinding does not improve the activity. At the same time, after $24 \mathrm{~h}$ of reaction with $\mathrm{Ca}(\mathrm{OH})_{2}$, activities are still close and both MK 15 and MK 30 have similar values 0.0483 that is more than after $3 \mathrm{~h}$, and it indicates that after $24 \mathrm{~h}$ the reaction has occurred more completely.

Activity after $3 \mathrm{~h}$ for DC 15 is lower than for DC 30 (0.0319 and 0.0430 ), which probably means that longer time of grinding has improved the activity of DC. Activity of DC 15 after 24 hours of reaction is 0.0332 , i.e., slightly higher than after $3 \mathrm{~h}$, but for DC 30, on the contrary, it has decreased to 0.0357. Although in this case the values are close, it could indicate that for DC the reactions with lime more intensively occur during the first hours. At the same time, it could be mentioned that despite the fact that all obtained values are rather close, MK 15 seems to be more active from both clays after 24 hours of reaction.

The shape of CA particles is rather similar independently of the treatment parameters - irregular, angular, with porous surface, but the specific surface area of particles is $11.64 \mathrm{~m}^{2} / \mathrm{g}$ and $9.849 \mathrm{~m}^{2} / \mathrm{g}$, respectively for particles ground for $4 \mathrm{~min}$ and 45 min, i.e., after longer grinding time, the specific surface area decreases, in contrast to what was expected. Obviously, the optimal grinding time has been exceeded and particles have started to form agglomerates. This also explains why the pozzolanic activity for CA 45 is lower than that for CA 4, despite the fact that the amount of reactive $\mathrm{SiO}_{2} / \mathrm{R}_{2} \mathrm{O}_{3}$ is higher for CA 45 particles. Respectively, for the values of specific surface area of $11.64 \mathrm{~m}^{2} / \mathrm{g}$ and $9.849 \mathrm{~m}^{2} / \mathrm{g}$, the corresponding values of reactive $\mathrm{SiO}_{2} / \mathrm{R}_{2} \mathrm{O}_{3}$ are $1.51 \% / 6.35 \%$ and $2.13 \% / 7.37 \%$, while for the particles ground for $4 \mathrm{~min}$ or $45 \mathrm{~min}$, the pozzolanic activity $-0.0402 \% / 0.0220 \%$ and $0.0340 \% / 0.0203 \%$ (see Tables 4 and 5 ).

For the particles obtained from glass powder, the shape is irregular, sharp-edged with smooth surface (glass powder BSG and LSG), but in this case, particles with a larger specific surface area are more active, e.g., if for BSG glass particles, the specific surface area is $1.126 \mathrm{~m}^{2} / \mathrm{g}$, but pozzolanic activity after $1 \mathrm{~h}$ and $3 \mathrm{~h}$ is 0.02688 and 0.00952 , then for LSG glass particles with surface area of $0.0252 \mathrm{~m}^{2} / \mathrm{g}$, pozzolanic activity is 0.01568 both after $3 \mathrm{~h}$ and $24 \mathrm{~h}$. Consequently, although both types of glass have a particular pozzolanic activity, it is possible that in concrete mix they would act first of all as a micro additive for filler.

It could be expected that comparing different particles with a similar shape - irregular, angular and with close values of a specific surface area, e.g., CA 4 and BSG (with a surface area of $11.64 \mathrm{~g} \mathrm{~m}^{2} / \mathrm{g}$ and $11.20 \mathrm{~g} \mathrm{~m}^{2} / \mathrm{g}$ ), also the pozzolanic properties will be close; however, the content of reactive $\mathrm{SiO}_{2} / \mathrm{R}_{2} \mathrm{O}_{3}$ differs significantly - for CA 4 it is $1.51 \% / 6.35 \%$ that is much more than in BSG powder $-0.50 \%$ and $0.36 \%$. This could be related to the surface morphology of coal ash particles, which is more porous, as well as to a different chemical composition.

Regarding wood and barley ashes (bio ashes), the shape is irregular and angular; however, the values of specific surface area are significantly lower, i.e., the particles of bio ashes are larger. If to compare both ashes, a specific surface area is larger for barley, although the content of reactive $\mathrm{SiO}_{2} / \mathrm{R}_{2} \mathrm{O}_{3} \%$ is significantly lower, at the same time the pozzolanic activity for barley ashes is higher than for wood ashes. Thus, it could be concluded that also for this group of SCM particles with a larger specific surface will be more pozzolanically active. In other 
words, for particles of similar origin and chemical composition, the pozzolanic activity will be determined by a specific surface area as well as the surface morphology.

If to compare the values of specific surface area and pozzolanic properties for particles with similar size, e.g., for CA 45 with dominant particle size of $800 \mathrm{~nm}-900 \mathrm{~nm}$ and DC 30 with average particle size of $800 \mathrm{~nm}$ (see Table 6), it could be concluded that the specific surface area depends both on the shape and the surface morphology of particles.

\section{TABLE 6}

COMPARISON OF SPECIFIC SURFACE AREA AND CONTENT OF REACTIVE $\mathrm{SIO}_{2} / \mathrm{R}_{2} \mathrm{O}_{3}$ FOR PARTICLES WITH A SIMILAR SIZE

\begin{tabular}{|l|l|l|l|}
\hline \multicolumn{1}{|c|}{ SMC } & $\begin{array}{c}\text { Dominant } \\
\text { particle size, } \\
\text { nm (obtained } \\
\text { by DSL) }\end{array}$ & $\begin{array}{c}\text { Specific } \\
\text { surface area, } \\
\mathrm{m}^{2} / \mathrm{g} \text { (BET) }\end{array}$ & $\begin{array}{c}\text { Content of } \\
\mathrm{SiO}_{2} / \mathrm{R}_{2} \mathrm{O}_{3}, \\
\mathrm{wt} \%\end{array}$ \\
\hline DC 30 & 798.6 & 21.42 & $1.05 / 7.79$ \\
\hline MK 15 & 840.3 & 16.52 & $1.10 / 32.76$ \\
\hline CA 45 & 882.5 & 9.849 & $2.13 / 7.37$ \\
\hline
\end{tabular}

Placing SCM consecutively from particles with smaller size to larger (see Table 7), no interconnection with corresponding surface area values could be observed that once again confirms that for particles with similar size, the specific surface could be significantly different and, thus, also the pozzolanic activity.

TABLE 7

COMPARISON OF PARTICLE SIZE AND SPECIFIC SURFACE AREA OF DIFFERENT $\mathrm{SCM}$

\begin{tabular}{|l|l|l|}
\hline \multicolumn{1}{|c|}{ SCM } & \multicolumn{1}{|c|}{$\begin{array}{l}\text { Dominant particle size, } \\
\text { nm (obtained by DSL) }\end{array}$} & \multicolumn{1}{|c|}{$\begin{array}{c}\text { Specific surface area, } \\
\mathrm{m}^{2} / \mathrm{g} \text { (BET) }\end{array}$} \\
\hline MK 20 & 522.8 & 19.54 \\
\hline MK 30 & 541.1 & 15.86 \\
\hline DC 15 & 541.8 & 21.96 \\
\hline DC 20 & 723.8 & 22.17 \\
\hline DC 30 & 798.6 & 21.42 \\
\hline MK 15 & 840.3 & 16.52 \\
\hline CA 45 & 882 & 9.849 \\
\hline CA 4 & 2083.9 & 11.64 \\
\hline
\end{tabular}

\section{CONCLUSIONS}

If to compare the particles with similar chemical composition, i.e., with similar content of reactive $\mathrm{SiO}_{2}$ and $\mathrm{R}_{2} \mathrm{O}_{3}$, the particles with a larger specific surface area will be more pozzolanically active, but if to compare the particles with equal or similar shape, the particles containing larger amount of reactive $\mathrm{SiO}_{2}$ and $\mathrm{R}_{2} \mathrm{O}_{3}$ will be more active. The higher the values of specific surface are, the better the pozzolanic properties of material are.

The surface area for particles with similar size could be different that indicates the different morphology. At the same time, the pozzolanic activity for particles with similar size could be different, if the morphology is different, independently of the similarities in shape.

Metakaoline and Devonian clay, coal ashes, both waste glass powders, wood and barley ashes, could be used as an additive or micro filler for concrete aggregate as well as the supplementary cementing material, improving the properties of high performance concrete.

\section{ACKNOWLEDGEMENTS}

The research has been carried out within the framework of ERDF Project "High Performance Nanoconcretes" (No 2010/0286/2DP/2.1.1.1.0/10/APIA/VIAA/033).

\section{REFERENCES}

[1] Li, Z. Advanced Concrete Technology. New Jersey: John Wiley \& Sons, Inc., Hoboken, 2011, p 506. http://dx.doi.org/10.1002/9780470950067

[2] Day, K.W. Concrete Mix Design, Quality Control and Specification. $3^{\text {rd }}$ ed., Taylor \& Francis, 2006, p 217.

[3] Aitcin, P.-C. Binders for Durable and Sustainable Concrete. In: Modern Concrete Technology 16. Taylor \& Francis, New York, 2008, pp. 273-313.

[4] Lea's Chemistry of Cement and Concrete. Ed. Hewlett, P.C., Elsevier, 2006

[5] Kara, P., Korjakins, A. Concrete with fluorescent waste glass suspension. In: Proceedings of 8th International Conference: Concrete in the Low Carbon Era 2012, Dundee, UK, 2012, pp. 719-728.

[6] Vittori, C., Cereseto, A. Solubilizzazione progressiva della silice e $\mathrm{R}_{2} \mathrm{O}_{3}$ dei materiali pozzolanici sotto l'azione della calce per valutazione del valore idaulico dei materiali stessi. La Chimica e L'Industria, 1935

[7] Setina, J., Krage, L., Juhnevica, I., Skripkina, T., Shakhmenko, G. The Influence of Different Pozzolanic Admixtures on Structure and Properties of Concrete. In: Proceedings of International Conference on Building Materials "18. ibausil", Weimar, Germany, 2012

[8] Massazza, M.F. Structure of pozzolana and fly-ash and the hydratation of pozzolanic and fly ash cements. In: Proceedings of 7 th International Congress on chemistry of cement, vol. 4, Paris, France, 1980, pp. 85-91.

[9] Massazza, M.F., Costa, U. Aspects of the pozzolanic activity and properties of pozzolanic cements. Il Cemento 76, 1976, pp. 3-18.

Linda Krage, Dr. sc. ing. (1999), Associate Professor at Riga Technical University, Faculty of Material Science and Applied Chemistry, Institute of Silicate Materials. She is the author of more than 75 publications in the field of inorganic binders, ceramics, concrete and restoration. Main direction of the research is dedicated to the studies of historical inorganic binders.

Address: Azenes Str. 14/24, Riga, LV-1048, Latvia.

E-mail: linda.krage@gmail.com

Diana Bajare, Dr. sc. ing., Associate Professor, Faculty of Civil Engineering, Institute of Materials and Structures, RTU.

Address: Azenes Str. 16/20, Riga, LV-1048, Latvia.

E-mail: diana.bajare@bf.rtu.lv

Aleksandrs Korjakins, Dr. sc. ing., Professor, Institute of Materials and Structures, Riga Technical University, Chair of Professors' Group of Building Materials and Products. Field of research: building materials and structures, ecological building materials, reuse of industrial waste.

Address: Azenes Str. 16, Riga, LV-1048, Latvia.

E-mail: aleksandrs.korjakins@rtu.lv

Janina Setina, Dr. sc. ing. (1977), Riga Polytechnical Institute (since 1992 Riga Technical University).

Work experience: since 1972 - Riga Technical University, Institute of Silicate Materials, Senior Research Scientist, Assistant Professor; since 1999 - the Head of the Testing Laboratory of Silicate Materials.

She is the author of 126 scientific publications; supervisor of Bachelor, Master, and Doctoral Theses.

E-mail: janina@ktf.rtu.lv

Inna Juhnevica, Dr. sc. ing. (2003), Riga Technical University. Since 1998, she has been working as a Senior Research Scientist, Assistant Professor at the Institute of Silicate Materials, Riga Technical University. She is the author of 19 scientific publications; supervisor of Bachelor, Master Theses.

Address: Azenes Str. 14/24, Riga, LV-1048, Latvia.

E-mail: innaju@ktf.rtu.lv 
Inta Kirilovica - Mg. sc. ing. (2013), 1st year doctor's student in Riga Technical University, Faculty of Material Science and Applied Chemistry, studying at chemical technology program. For six years has been working in the Laboratory of Chemical Analysis of Silicates in the Institute of Silicate materials, Faculty of Material Science and Applied Chemistry. The main direction of the work is dedicated to restoration of the stone materials. Address: Azenes str. 14/24, Riga, LV-1048, LATVIA

E-mail: inta.kirilovica@gmail.com

\section{Linda Krāg̣e, Diāna Bajāre, Aleksandrs Korjakins, Jan̄̄na Sētiṇa, Inna Juhṇeviča, Inta Kiriloviča. Pētījumi par sakarību starp dažādu HPC mikropildvielu morfologiju un pucolānu aktivitāti}

Saistoties portlandcementa minerāliem - trikalcija silikātam $\left(\mathrm{C}_{3} \mathrm{~S}\right)$ un tetrakalcija alumoferītam $\left(\mathrm{C}_{4} \mathrm{AF}\right)$ - hidrolīzes reakcijās, papildus hidrauliskajiem savienojumiem kalcija hidrosilikātiem vai aluminātiem (CHS vai CHA), veidojas arī portlandīts $\mathrm{Ca}(\mathrm{OH})_{2}$, kam nav hidraulisku îpašību. Tāpēc, bieži tiek izmantotas aktīvās minerālās piedevas, kas reag̣e ar šo $\mathrm{Ca}(\mathrm{OH})_{2}$, veidojot sekundāros kalcija hidrosilikātus vai aluminātus.

Darbā pētītas dažādu smalki dispersu materiālu īpašības. Šie materiāli ir potenciālas aktīvas minerālās piedevas - termiski apstrādāti māli (importēts kaolīns un Latvijas devona māli (Liepas atradne), apdedzināti $700{ }^{\circ} \mathrm{C}$ ), tādi atkritumprodukti kā akmeņog̣̣lu pelni, atkritumu stikla pulveri, koksnes pelni un miežu pelni. Analizētas sekojošas piedevu īpašības: īpatnējās virsmas laukums (noteikts, izmantojot BET metodi), virsmas morfolog̣ija (SEM), daliṇu izmēru sadalījums, ķīmiskais sastāvs (aktīvā $\mathrm{SiO}_{2}$ un $\mathrm{R}_{2} \mathrm{O}_{3}$ (kopējais $\mathrm{Al}_{2} \mathrm{O}_{3}, \mathrm{Fe}_{2} \mathrm{O}_{3}$ un $\mathrm{TiO}_{2}$ ) saturs, kā arī pucolānu aktivitāte jeb kaḷka saistīšanas spēja, reağējot ar $\mathrm{Ca}(\mathrm{OH})_{2}$. Iegūtie rezultāti rāda, ka dalinu smalkumam ir būtiska nozīme kaḷka-pucolāna reakcijā, aktīvākas ir mikropiedevas ar lielāku īpatnējo virsmu. Tomēr šis pieņēmums ir spēkā līdz optimālajam daḷiņu smalkumam, un tālāka daḷiņu malšana nesniedz apmierinošus rezultātus, jo malšanas laikā dạininas veido aglomerātus, kurus nepieciešams disperǵēt šḳīdumā labākai reakcijai ar kaḷki. Vienāda vai līdzīga izmēra daḷin̄ām atšḳirīgas morfolog̉ijas dēḷ var būt atšḳirīgas īpatnējā virsmas laukuma vērtības, kas būtiski ietekmē arī pucolāna īpašības. Noteikts, ka pētìtās piedevas izmantojamas gan kā papildus cementējošs materiāls - aktīvā minerālā piedeva, gan kā mikropildviela jeb piedeva betona pildvielai.

\section{Линда Краге, Диана Баяре, Александрс Корякинс, Янина Сетиня, Инна Юхневича, Инта Кириловича. Изучение взаимосвязи} между морфологией и пуццоллановой активностью различных микронаполнителей для НРС

Связываясь между собой, минералы портландцемента - трикальций силикат $\left(\mathrm{C}_{3} \mathrm{~S}\right)$ и тетракальций алюмоферрит $\left(\mathrm{C}_{4} \mathrm{AF}\right)$, в результате гидролиза в дополнение к гидравлическим соединениям - гидросиликату или алюминату кальция, образуют также портландит Са(ОН) 2 , который не обладает гидравлическими свойствами. Поэтому часто используют активные минеральные добавки, которые реагируют с $\mathrm{Ca}(\mathrm{OH})_{2}$, образуя вторичные гидросиликаты или алюминаты кальция.

В работе исследованы свойства различных мелкодисперсных материалов или потенциальных активных минеральных добавок термически обработанной глины (импортированный каолинит и девонская глина латвийского происхождения (месторождение Лиепа), обожженные при $700{ }^{\circ} \mathrm{C}$ ), а так же продуктов отходов - угольной золы, порошка стекла, древесного и ячменного пепла. Анализированы следующие свойства: удельная площадь поверхности (БЕТ), морфология поверхности (СЭМ), распределение размеров частиц, химический состав (содержание реакционноспособных $\mathrm{SiO}_{2}$ и $\mathrm{R}_{2} \mathrm{O}_{3}$ (общее количество $\mathrm{Al}_{2} \mathrm{O}_{3}, \mathrm{Fe}_{2} \mathrm{O}_{3}$ и $\mathrm{TiO}_{2}$ )), а так же пуццоллановая активность или реакционная способность извести и $\mathrm{Ca}(\mathrm{OH})_{2}$. Полученные результаты показали, что размер частиц имеет огромное влияние на известково-пуццоллановую реакцию, более реактивными являются микродобавки с большей удельной поверхностью. Однако это предположение действительно до какого-то оптимального размера частиц, так как дальнейшее уменьшение размера частиц не дает удовлетварительных результатов и указывает на формирование агломератов в процессе помола, которые нужно диспергировать в растворе для лучшей реакции с известью.

Частицы идентичного или аналогичного размера из-за различной морфологии могут различаться значениям площади удельной поверхности, что значительно влияет на пуццоллановые свойства. Определено, что исследованные добавки могут быть использованы как дополнительный цементирующий материал - активная минеральная добавка, а также как микронаполнитель или добавка к наполнителю бетона. 